\title{
ヒト白血球からのライソゾーム酵素が 歯周組織に与える影響について
}

(ウサギにおける実験的研究)

\author{
萩原さつき \\ 東京医科歯科大学歯学部第 2 保存学教室 \\ (歯周治療学講座) \\ (主任, 指導 : 木下四郎教授) \\ (昭和 54 年 9 月 20 日受付)
}

\author{
Possible Role of Lysosomal Enzymes in Process of Periodontal Destruction \\ (An experimental study in rabbit) \\ Satsuki HAGIWARA \\ Department of Periodontology, School of Dentistry, \\ Tokyo Medical and Dental University. \\ (Chief and Director: Prof. Shiro KINOSHITA)
}

The aim of this study was to observe whether the lysosomal enzymes from human polymorphonuclear leukocytes were capable of destroying periodontal tissue in vivo, when the enzymes were applied into the rabbit gingival sulcus.

Human leukocytes were prepared by sedimentation of heparinized blood. A granule fraction was extracted from homogenate of leukocytes by centrifugation. The granule extract was obtained by freezing and thawing and subsequent centrifugation. A neutral protease of the granule extract was partially purified by a gel chromatography. From the result of biochemical analysis, it was found that the neutral protease fraction exhibited both proteolytic and elastolytic activities. The optimum $\mathrm{pH}$ of the neutral protease was approximately 8.3-8.9 with regard to its proteolytic activity. The molecular weight of the enzyme was estimated as $25,000 \pm 3,000$ by a gel chromatography.

All rabbits were given the drinking water containing $0.05 \%$ tetracycline hydrochloride for two weeks prior to the experiment to decrease the microorganisms in the crevices. Labial crevices of mandibular incisors of rabbits were used as experimental sites. The strips of filter papar were inserted into those crevices, then the granule extract and the neutral protease were dropped on the filter papar every ten minutes for six hours by tubercline syringe. Saline solution and the heat-inactivated enzymes were used as controls.

Histological findings at experimental sites showed the ulceration of sulcular epithelium and inflammatory exudation in lamina propria. Leukocytic infiltrations into the epithelium were also observed especially at the site where the granule extract was applied. The connective tissue was slightly damaged in the neighborhood of the inflammatory cells at the experimental sites. Inflammatory alterations were hardly found at the three comparable regions of the control sites. The possibility of the direct or indirect destructive effects of lysosomal enzymes on periodontal tissues was indicated by this study. 


\section{I. 緒 言}

歯垢が堆積すると歯肉の内縁上皮下に急性浸出性炎が 起こり，内縁上皮の透過性が充進するとともに，結合組 織から歯肉溝中に主として多形核白血球が遊出する1 3)。

Attström 等(4)によとヒト歯肉溝中に存在する白血 球の中で多形核白血球の占める割合が最も大きく，歯肉 炎の進展に伴ってその数が増加する。

この多形核白血球の歯肉溝への遊走は, 歯垢中の細菌 に由来する細菌性遊走因子，あるいは免疫複合物や細菌 産生物などにより補体が活性化され生成された白血球遊 走因子によって起こることが知られている る5,6)。歯肉溝 中に遊走した多形核白血球は, 電顕的研究によると歯垢 と歯肉組織との間に一層を形成する像が報告されており 7)，また歯肉溝中で歯垢中の細菌を貪食することも知ら れている ${ }^{8,9) 。 ~}$

このような事実から歯肉溝中で多形核白血球が抗菌的 あるいは殺菌的に働き，生体防禦において重要な役割を 果たしていると考えられている4,9,10)。

しかし実際に殺菌作用が行なわれているかどうか，ま た多形核白血球による細菌の食食が歯周疾患の病因論に おいてどのような役割を果たすかということは明確にさ れていない。Freedman 等 ${ }^{11)}$ は，歯肉溝中には多くの多 形核白血球と細菌が存在するにもかかわらず貣食像は稀 にしか見られなかったと発表している。最近 Wilton 等 ${ }^{12)}$ は静脈血中の多形核白血球に比較すると歯肉溝中に遊 出した多形核白血球は Candida albicans の芽胞を貪食 する能力が低いことを報告した。in vitro で歯垢中の細 菌と多形核白血球との相互作用についても様々な研究が

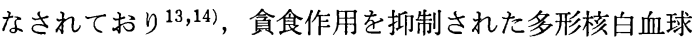
も歯垢中の細菌による刺激を受けるとライソゾーム酵素 を放出することが確認された ${ }^{13)}$ 。

このように歯肉溝中において多形核白血球は頜食作用 に加えて細菌性内毒素 ${ }^{15)}$, 活性化された補体系の成分 ${ }^{16)}$, 歯垢中の細菌崩壊産物 ${ }^{17)}$, 免疫複合物 ${ }^{18)}$ 等により刺激さ れてライソゾーム酵素を放出する。

炎症の際には多形核白血球の顆粒中の酵素が組織障害 をひき起こす可能性もあることが示唆されている。

白血球のライソゾーム酵素については組織学的, 生化 学的, あるいは免疫学的に研究されて, かなり詳細に知 られている。

多形核白血球には，その細胞質内に他の細胞では認め
られない程多くの顆粒が存在し, 多種類のライソゾーム 酵素を含有する。

顆粒は電子顕微鏡的, 組織化学的な所見から 2 つの型 に分類されている。アズール顆粒は比較的大型で電子密 度が高くペルオキシダーゼ陽性でlysosomal hydrolases, neutral serine protease, bactericidal elements (myeloperoxidase, lysozyme) を含み, 特殊顆粒は小型で電 子密度が低くペルオキシダーゼ陰性で collagenase, 1ysozyme, lactoferrin を含むが lysosomal hydrolases は 持っていない。このうち neutral serine protease に関 しては, elastase, cathepsin G と third enzyme の 3

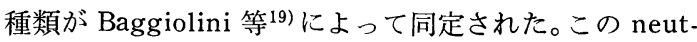
ral protease は顆粒蛋白の中では大きな比率を占めてい て, 多形核白血球が細胞外に酵素を放出してひき起こさ れる反応の中で最も重要なメディエーターであると考え られている。

この neutral protease を血管の基底膜，軟骨の proteoglycan, 肺結合組織, elastin, collagen, 糸球体基底 膜, C 5, Cls, fibrin, plasminogen, Kininogen ${ }^{20)}, \mathrm{IgG}^{21}$, 22)細菌の細胞膜 ${ }^{23)}$ 等に作用させると, これらを崩壊させ ることが知られている。

ところで, ヒト歯肉溝浸出液は酸性領域おいて蛋白分 解酵素の活性があるとともに，中性，アルカリ性領域に おいても蛋白分解酵素活性を示すことが確められてお り，細菌由来の酵素を除外することはできないが，中性 領域で活性を示す蛋白分解酵素は多分ほとんど歯肉溝中 に遊出する多形核白血球に由来すると考えられている 24)。

また Ohlsson 等 ${ }^{25)}$ は, このヒト歯肉溝中に存在する neutral protease は elastase に類似した酵素であり，歯 肉に炎症がある場合には collagenase と同様にこの酵素 の活性が増大することを報告している。

しかし，これら白血球に由来するライソン゙ーム酵素が in vivo において歯周組織にどのような影響を与えてい るかということについてはまだ知られていない。

最近 Heiniger 等 ${ }^{24)}$ はヒト白血球から抽出し，部分的 に精製した neutral protease を,切除してただちに凍結 した後クリオスタットで薄切したヒト歯肉片に滴下し て, in vitro で $37^{\circ} \mathrm{C} 2$ 時間 incubation した後, ホルマ リンで固定し PAS 染色を行なったところ，歯肉上皮は 著しく崩壊し基底膜も損傷を受け固有層のコラーゲン線 維束も変性したことと, 白血球から得られた顆粒抽出液 や，cathepsin D を作用させた時にも同様の結果を得た こと，またこの反応系にヒトの血清を加えた時にはほと 
んど変化が見られなかったことを観察した。

今回ヒト白血球からライソゾーム酵素を抽出し, 次に それらの酵素を in vivo で歯周組織に作用させた時, こ れが歯肉にどのような病的変化をひき起こすかを検索す るために本研究を行なった。

\section{II. 実験材料及び方法}

\section{1.ヒト白血球からのライソゾーム酵素の抽出法と,} その生化学的検索法

a）ヒト白血球から granule extract（顆粒抽出液） の抽出方法

Ishikawa 等の方法 ${ }^{22)}$ に準じて行なった。ヒト末梢血 （日赤赤血球濃厚液, 容量 $130 \mathrm{~m} l, 3$ パック）に同量の 5 $\%$ dextran (grade A, mol. wt 200,000 275,000 BDH biochemical Ltd, 生理的食塩水を溶媒としたもの) を加 え 1 時間室温で放置した。大部分の赤血球は凝集し沈渣 となり，白血球は上清に集まった。この白血球を含む上 清を $120 \mathrm{~g}, 8$ 分間 $4^{\circ} \mathrm{C}$ で遠沈し, 赤血球, 血小板, 血漿 を除去して白血球を分離した。沈渣中には少量の赤血球

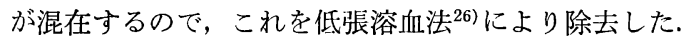
即ち，まず得られた白血球を多く含む沈渣に同量の生理. 的食塩水を加え heparin $(1,000$ 単位 $/ \mathrm{m} l)$ を滴加して㲘 濁させた。これに全容量の 3 倍の蒸留水 $\left(4^{\circ} \mathrm{C}\right)$ を加え て 30 秒間激しく混合して赤血球を溶血させた後, 先に 加えた蒸留水の $1 / 3$ 量の $3.5 \% \mathrm{NaCl}\left(4^{\circ} \mathrm{C}\right)$ を加え良く 攪汼して等張溶液にもどした。 $4^{\circ} \mathrm{C}, 150 \mathrm{~g}$ で遠沈し破壊 された赤血球を含む上清を棄てた。沈渣に残った白血球 を, 生理的食塩水で 3 回, $0.34 \mathrm{M}$ sucrose で 1 回洗っ た。この時, $0.34 \mathrm{M}$ sucrose で洗う直前に沈渣を $10 \mathrm{~m} l$ の生理的食塩水に䀣濁させて白血球数を haemocytometer で計測し, 塗沫標本を作り May GrunwaldGiemsa 染色を行なって観察した。白血球数は $8.96 \times 10^{7}$ 個 $/ \mathrm{m} l$, その種類と含有率は, 多形核白血球が $87.2 \%$, 好酸球が $2.3 \%$, 好塩基球が $1.7 \%$, 単核白血球（リン 分球と単核球を含む）が $8.8 \%$ であった（図 1)。

$0.34 \mathrm{M}$ sucrose で洗った後,得られた白血球を $0.34 \mathrm{M}$ sucrose $10 \mathrm{~m} l$ に懸滥させた。これをガラスホモジナイ ザー(容量 $20 \mathrm{~m} l$ ) 中に入れ周囲を水冷し低温下で 5 回木 モジナイズした。この際 1 回につき 1 分間ホモジナイズ し, 30 秒間休止するというように内部の温度が上がら ないよらに注意した。 $4^{\circ} \mathrm{C}, 600 \mathrm{~g}$ で 10 分間遠沈を行な い核分画を沈澱させ上清を分離した。沈渣に再び $5 \mathrm{~m} l$ の $0.34 \mathrm{M}$ sucrose を加えて同条件下でホモジナイズし

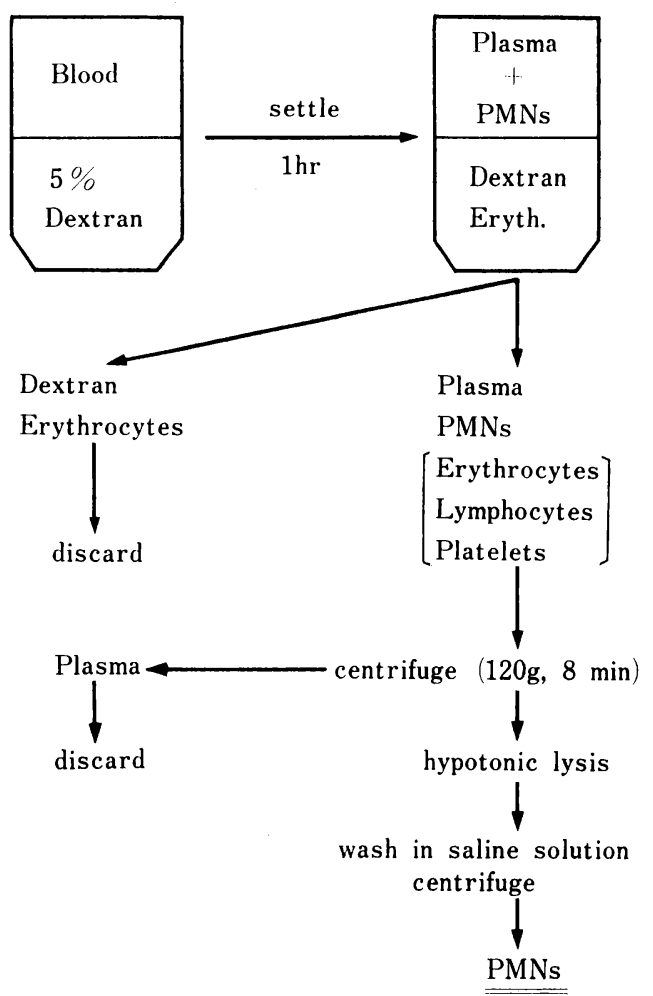

図 1 末梢血からの白血球分離

て遠沈を行ない，上清を集めて，これを先に得た上清に 加えた。なおホモジナイズに際しては白血球が破壊され ている状態を haemocytometer で確認した。最初のホ モジナイズでほぼ $80 \%$ 破壞されていた。

次にこの上清を $4^{\circ} \mathrm{C}, 20,000 \mathrm{~g}$ で 20 分閒遠沈を行な い, 沈渣に granule fraction (顆粒分画) を得た。この 中にライソジームが含まれる。（図 2）

この granule fraction に $2 \mathrm{~m} l$ の $20 \mathrm{mM}$ リン酸緩衝 液 ( $\mathrm{pH}$ 7.0) を加え freezing and thawing 3 回繰り 返し, 同量の $0.3 \mathrm{M} \mathrm{NaCl}$ を加え $4^{\circ} \mathrm{C}, 20,000 \mathrm{~g}$ で 20 分閒遠沈を行なった。ライソゾーム䤃素が遊離した上清 を別にして, 沈渣に再び $20 \mathrm{mM}$ リン酸緩衝液 (pH 7.0) を $1 \mathrm{~m} l$ 加え, 同じ条件下で freezing and thawing, 遠沈を行なって $6 \mathrm{~m} l$ の上清を granule extract (顆粒抽 出液）として得た。

b ）ゲル滤過クロマトグラフィー

顆粒抽出液 $3.5 \mathrm{~m} l$ を用いてゲル濾過クロマトグラフ イーを行なった。 $0.15 \mathrm{M} \mathrm{NaCl}$ を含む $10 \mathrm{mM}$ リン酸緩 衝液( $\mathrm{pH}$ 7.3) 中に膨潤させた Sephadex G-75 superfine を $1.5 \times 90 \mathrm{~cm}$ のカラムに充填したものを用いた。流速 
は $2.5 \mathrm{~m} l /$ 時間, 溶出量は各試験管に $2.3 \mathrm{ml}$ として行な った。

c) 生化学的定量

a ）で得られた顆粒抽出液，b）で得られた部分的に 精製した酵素について生化学的に定量を行なった。

(1) 蛋白質の定量一Lowry 法 ${ }^{27)}$ を用いて定量した。

(2) 蛋白分解酵素活性一へモグロビンを基質として定 量した。0.1 M リン酸緩衝液（pH 7.3）を $0.5 \mathrm{ml}, 6 \%$ ヘモグロビン (Sigma Type II, 最終濃度 1.5\%) を 0.2 $\mathrm{m} l$ 酵素溶液 $0.1 \mathrm{~m} l$ に加えて $37^{\circ} \mathrm{C} 3$ 時間 incubation を行なった。この後 $0.3 \mathrm{~N}$ トリクロール酢酸を加えて 滤過した。blank としては incubation する前に $0.3 \mathrm{~N}$ トリクロール酢酸を $3 \mathrm{~m} l$ 加えたものに酵素溶液 $0.1 \mathrm{~m} l$ を加えて同条件下で行なった。濾過して得られた溶液 $0.5 \mathrm{~m} l に 2.5 \mathrm{~m} l$ のアルカリ性銅試薬を加えて 10 分間 室温で放置し，2 倍稀釈した Folin 試薬 $0.2 \mathrm{ml}$ を加えて 発色させ 30 分後に 102 型日立分光光度計で $750 \mathrm{~nm}$ に おける吸光度を測定した。

また蛋白分解酵素活性の $\mathrm{pH}$ 依存性について調べる場 合は同じ条件下で緩衝液を変えて定量した。用いた緩衝 液は次の 4 種類である。

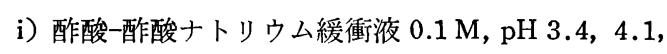
$4.9,5.8$, ii） リン酸緩衝液 $0.1 \mathrm{M}, \mathrm{pH} 5.5,6.2,7.4$, 8.1, $\mathrm{iii} ）$ トリス・ $\mathrm{HCl}$ 緩衝液 $0.1 \mathrm{M}, \mathrm{pH} 7.1,7.9,8.3$, 8.9 , iv) 炭酸ナトリウム一炭酸水素ナトリウム緩衝液 $0.1 \mathrm{M}, \mathrm{pH} 9.5,10.0$ 。

(3) エラスターゼ活性一基質として合成基質, N-tertButoxycarbonyl-L-Alanine-p-Nitrophenyl Ester (NBA Sigma B 5126) を用て定量を行なった ${ }^{28,29) 。 3 \times 10^{-3} \mathrm{M}}$ リン酸緩衝液 ( $\mathrm{pH} \mathrm{6.5)} 3 \mathrm{ml}$ を準備し, 反応開始 1 分前 に $10^{-2} \mathrm{M} \mathrm{NBA}$ (メタノール溶液中) $0.1 \mathrm{~m} l$ を加え反応 開始時に $0.1 \mathrm{~m} l$ の酵素溶液を加えて石英セル中で反応 させた。その後 $5,7,9,11$ 分後に経時的に $347.5 \mathrm{~nm}$ での吸光度を測定した。

Blank は酵素溶液のかわりに蒝留水 $0.1 \mathrm{~m} l$ を用いて 定量した。標準溶液としては Elastase (Sigma NoE 1250）を用いて同様に定量を行ない，経時的な吸光度の 変化から標準線を描き，この直線の傾きからエラスター ゼ活性を計算した。

(4) ゲル濾過法による分子量の決定一部分的な精製に よって得られた neutral protease の分子量測定の為に Sephadex G-75 superfine を用いて, blue dextran 2000, Albumin from hen egg (mol. wt. : 45,000), Chymotrypsinogen A (mol. wt. : 25,000), cytochrome C

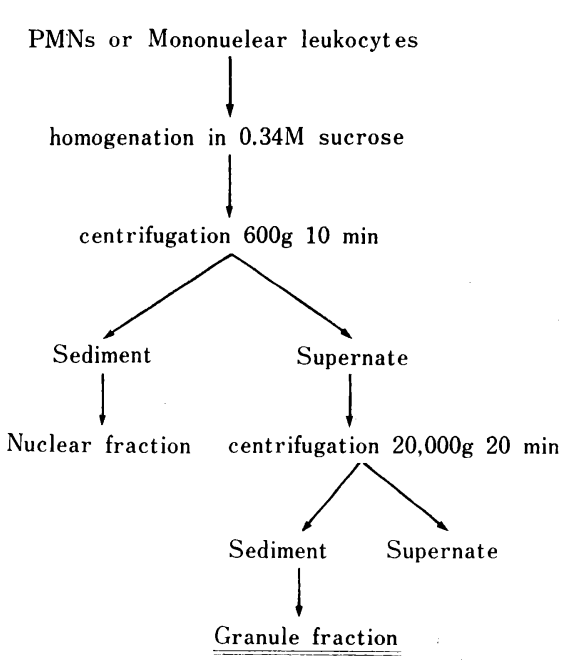

図 2 Granule Fraction (顆粒分画) の抽出

(mol. wt. : 12,500) を溶出させた。

void volume (Vo) を blue dextran 2000 により決定 $し \mathrm{Ve} / \mathrm{Vo}$ を Andrew の方法 ${ }^{30}$ に従って計算して分子量 を求めた。

ヒト末梢血中の白血球からのライソゾーム醉素の抽 出, 部分的な精製は 5 回行ない, 蛋白質量, 蛋白分解酵 素活性，その $\mathrm{pH}$ 依存性，エラスターゼ活性については 平均值を計算した。なお 1 検体につき 3 回ずつ定量し た。分子量決定に際しては 3 回定量を行ない, その平均 值を得た。

2. ヒト白血球から得た酵素のウサギ歯肉組織への 作用方法

a) 動物実験は体重 2 4 kg 今の家鬼を用いて行なっ た。前処置として実験開始 2 週間前から $0.05 \%$ テトラ サイクリン（アクロマイシン粉末：武田薬品）を含む飲 料水を投与した ${ }^{31)}$ 。予備実験の段階で前処置を行なって いない家鬼について調べたところ, 歯肉溝上皮下に軽度 の炎症所見が大部分の例に見られたので, 歯肉溝中の細 菌丵の增殖を防ぐために抗生物質を経口投与した。その 結果歯肉溝上皮下の炎症性細胞浸潤はほとんど見られな くなった。

実験時, 家鬼を開口させるのに都合が良いように改良 した固定箱に入れて開口させてから下頡切歯唇側歯肉溝 に濾紙片 (Whatman filter papers) 幅 $1 \mathrm{~mm}$ 長さ $5 \mathrm{~mm}$ を雨入して 2 種類の酵素, i) 白血球の顆粒から粗酵素と して抽出した顆粒抽出液, ii） i）を部分的に精製して得 られた neutral protease, 各 $0.5 \mathrm{~m} l$ を 10 分間隔で 6 時 


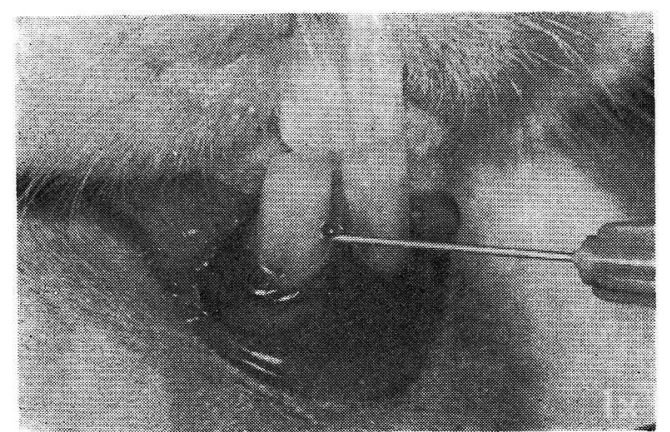

図 3 酵素溶液を歯肉溝に挿入したろ紙片上に 滴下しているところを示す

間，図 3 に示すようにツベルクリン注射針を用いて滴下 した。用いた酵素の蛋白質量, 中性蛋白分解酵素活性, エ ラスターゼ活性は表 3 に示す通り, 顆粒抽出液, neutral protease では各々蛋白質量は $1.85 \mathrm{mg} / \mathrm{ml}, 0.087 \mathrm{mg} / \mathrm{ml}$, 中性蛋白分解酵素活性は 0.775, 0.280 (750 nm におけ る吸光度), エラスターゼ活性は $1.12,0.27$ 単位であっ た。対照群としては同量の生理的食塩水, 及び i) ii）で 得られた酵素を 20 分間 $100^{\circ} \mathrm{C}$ で加熱して不活性化した ものを用いて行なった。

\section{b ) 組織学的検索}

実験終了後屠殺し顎骨を離断して $10 \%$ 中性ホルマリ ンで固定を行ないPlank Rychlo 迅速脱灰液で脱灰し た。通法に従ってパラフィン包埋して 8〜10 $\mu$ の厚さの 連続切片を作製し HE 染色, アザンマロリー染色, エラ スチカワンギーソン染色, PAS 染色を行なった。作製し た標本において歯肉溝上皮を図7のように上部，中間 部, 底部の 3 部分に分けて, 潰晹の有無, 上皮直下の固 有層における炎症性細胞の数, 上皮へ侵入した白血球数 について図 4 に示す様に接眼レンズに Eyepiece micrometer を装着して 200 倍で顕微鏡写真を撮影し，拡大鏡 を用いて観察した。使用した Eyepiece micrometer は $10 \mathrm{~mm}$ の正方形の中に縦横に $1 \mathrm{~mm}$ 幅の格子が切って あるもので, 対物レンズが 20 倍の場合は Eyepiece micrometer 上の $10 \mathrm{~mm} \times 10 \mathrm{~mm}$ の像は組織切片上で は $0.5 \mathrm{~mm} \times 0.5 \mathrm{~mm}$ に相当する。この実験では上皮固 有層については Eyepiece micrometer 上の 10 枠（組 織切片上では $25 \times 10^{-3} \mathrm{~mm}^{2}$ に相当した)。上皮について は 5 枠（組織切片上では $12.5 \times 10^{-3} \mathrm{~mm}^{2}$ に相当した） において炎症性細胞数, 白血球数を計測してその平均值 を求めた。

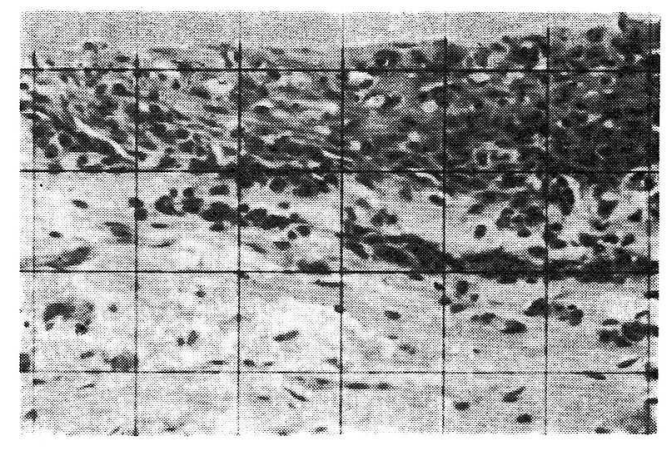

図 4 接眼レンズに Eyepiece micrometer を 装着して撮影した組織標本 $\quad \times 200$ HE 染色

\section{III. 結果}

\section{1. ヒト白血球から抽出したライソゾーム酵素につい $\tau$}

ゲル濾過クロマトグラフィーによって得られた溶出パ ターンを図 5 に示した。蛋白質の定量 ( $\Delta 280 \mathrm{~nm}$ におけ る吸光度を測定）によって4つのピークが得られた。中 性蛋白分解酵素活性のピークは, この蛋白質量定量によ って得られた 2 番目のピークに相当するところにあり， 他の 3 ピークには存在しなかった。この分画は溶出量約 $70 \mathrm{ml}$ で分子量は $25,000 \pm 3,00$ であった。またエラスタ 一ゼ活性のピークもこの点に一致することを確認した。 図 6 は $\mathrm{pH}$ を変化させた時のこの分画の蛋白分解酵素活 性の変化を現わしている。 $\mathrm{pH} 8.3 \sim 8.9$ で活性が最大で あることがわかった。表 1, 表 2 はゲル濾過クロマトグ ラフィーにより neutral protease を得て,この分画が蛋 白分解酵素活性とエラスターゼ活性の両者を持つ特異的 な酵素の分画であること, そして neutral protease に関 しては 12.5 倍に精製されエラスターゼに関しては 7.66 倍に精製されたという結果を示した。

2. ヒト白血球から得られたライソゾーム酵素を in vivo でウサギ歯肉組織に作用させた時の反応

家鬼切歯は萠出し続けていて, 3〜5 $\mathrm{mm}$ の生理的歯肉溝 が存在している。歯肉溝上皮は口腔粘膜と連続してお り，付着上皮は認められない。また歯肉溝底部よりも深 部まで上皮が存在している。この歯肉溝上皮の上部, 中 間部, 底部について組織学的に検索を行なった。図 7 は 家鬼下顎切歯唇側部を縦断した模式図である。

生理的食塩水を滴下した対照群の歯肉溝上皮では炎症 性細胞はほとんど見られなかった（図8）。 
表 1 ゲルロ過クロマトグラフィーを行なう前後に定量した中性蛋白分解酵素活性

\begin{tabular}{l|c|c|c|c|c}
\hline & $\mathrm{ml}$ & $\begin{array}{l}\text { Protein } \\
\text { conc. } \\
(\mathrm{mg} / \mathrm{ml})\end{array}$ & $\begin{array}{l}\text { Proteolytic } \\
\text { Activity } \\
(\triangle 750 \mathrm{~nm})\end{array}$ & $\begin{array}{l}\text { Specific } \\
\text { Activity }\end{array}$ & $\begin{array}{l}\text { Purification } \\
\text { Factor }\end{array}$ \\
\hline Granule Extract & 3.5 & 1.92 & 0.639 & 0.333 & 1 \\
\hline $\begin{array}{l}\text { G-75 gel } \\
\text { Chromatography }\end{array}$ & 16.1 & 0.073 & 0.303 & 4.15 & 12.5 \\
\hline
\end{tabular}

表 2 ゲルロ過クロマトグラフィーを行なう前後に定量したエラスターゼ活性

\begin{tabular}{l|c|c|c|c|c}
\hline & & $\begin{array}{l}\text { Protein } \\
\text { conc. } \\
(\mathrm{mg} / \mathrm{ml})\end{array}$ & $\begin{array}{c}\text { Elastase } \\
\text { Activity } \\
(\mu \mathrm{g} \text { protein/ml })\end{array}$ & $\begin{array}{l}\text { Specific } \\
\text { Activity }\end{array}$ & $\begin{array}{l}\text { Purification } \\
\text { Factor }\end{array}$ \\
\hline $\begin{array}{l}\text { Granule Extract } \\
\mathrm{ml}\end{array}$ & 3.5 & 1.92 & $\begin{array}{c}62.3 \\
0.93 \text { unit** }\end{array}$ & 0.032 & 1 \\
\hline $\begin{array}{l}\text { G-75 gel } \\
\text { Chromatography }\end{array}$ & 16.1 & 0.073 & $\begin{array}{c}17.9 \\
0.27 \text { unit }\end{array}$ & 0.245 & 7.66 \\
\hline
\end{tabular}

** I unit will solubilize I $\mathrm{mg}$ of Elastin in $20 \mathrm{~min}$ at $\mathrm{pH} 8.8$ at $37^{\circ} \mathrm{C}$.

表 3 家鬼下顎切歯唇側歯肉溝に滴下した酵素溶液の蛋白質量, 中性蛋白分解酵素活性, エラスターゼ活性

\begin{tabular}{c|c|c|c}
\hline & $\begin{array}{l}\text { Protein conc. } \\
(\mathrm{mg} / \mathrm{ml})\end{array}$ & $\begin{array}{l}\text { Proteolytic } \\
\text { Activity } \\
(\triangle 750 \mathrm{~nm})\end{array}$ & $\begin{array}{l}\text { Elastase } \\
\text { Activity } \\
\text { (unit) }\end{array}$ \\
\hline Granule Fraction & 1.85 & 0.775 & 1.12 \\
\hline Neutral Protease & 0.087 & 0.280 & 0.27 \\
\hline
\end{tabular}

(1) Granule Fraction : $0.5 \mathrm{ml}$

対照群において加熱処理をして不活性化した酵素を滴 下した例でも，生理的食塩水を滴下した時と同様，歯肉 溝上皮にはほとんど炎症性細胞浸潤は見られなかった (図 9, 10)。

顆粒抽出液を滴下した例での歯肉溝上部においては, 上皮中に白血球を中心とする炎症性細胞浸潤が起こり， 一部上皮が崩壊しているのが見られた（図 $11 \mathrm{~B}, \mathrm{C}$ )。 同組織の歯肉溝底部では上皮下に炎症性細胞浸潤が見ら 扎た（図 11 D，E）。neutral prateaseを滴下した歯肉 溝上部では上皮中に白血球の浸潤が起こり部分的に剝離 しているのが見られた（図 $12 \mathrm{~B}, \mathrm{C}$ )。同組織の歯肉溝 底部には上皮直下に炎症性細胞浸潤が見られた（図 12 D, E)。

歯肉溝上皮を 3 部位に分けて観察した結果, 表 4 に示 すように, 上皮下固有層に抢ける炎症性細胞の数, 上皮
(2) Neutral Protease : $0.5 \mathrm{ml}$

中に侵入した白血球数については, 実験群と対照群で統 計学的に有意の差が認められた。即ち上皮下固有層（上 部）における炎症性細胞の数は実験群では単位面積当り $132.5 \pm 45.3$ (顆粒抽出液を滴下した群), $70.8 \pm 25.5$ (neutral protease を滴下した群), 対照群では $31.2 \pm$ 10.6 であり, 上皮中に侵入した白血球数は実験群では 各 $87.3 \pm 19.9,40.2 \pm 17.9$, 対照群では $3.4 \pm 3.4$ であ つた。

また顆粒抽出液を滴下した例では全てに潰瘍が存在し ていた。これは歯肉溝上部で最も多く見られた。

弾性線維染色を行なったところ, 上皮下固有層の結合 組織において, 対照群に比較して実験群では炎症性細胞 の周囲で染色性が悪く, 部分的に線維が消失していた (図 13 A B C, 図 14 A B C)。

PAS 染色においても実験群では対照群に比較して, そ 
Gel filtration of granule fraction on a

Sephadex G-75 superfine column $(1.5 \times 90 \mathrm{~cm})$

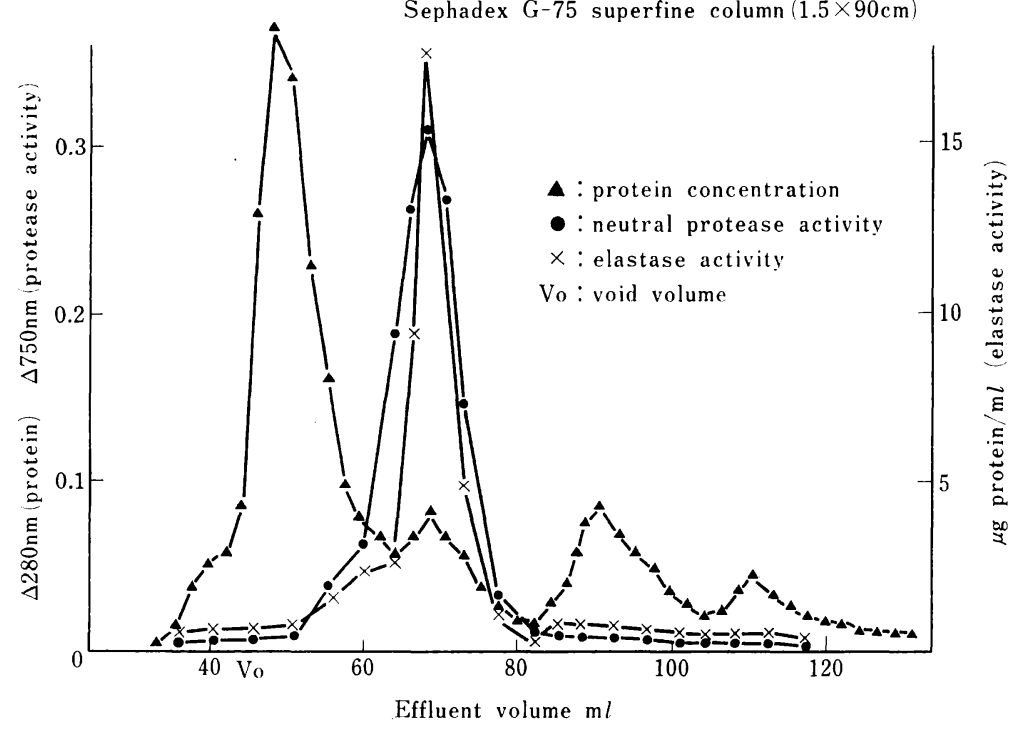

図 5 ゲルロ過クロマトグラフィーによって得られた溶出パターン

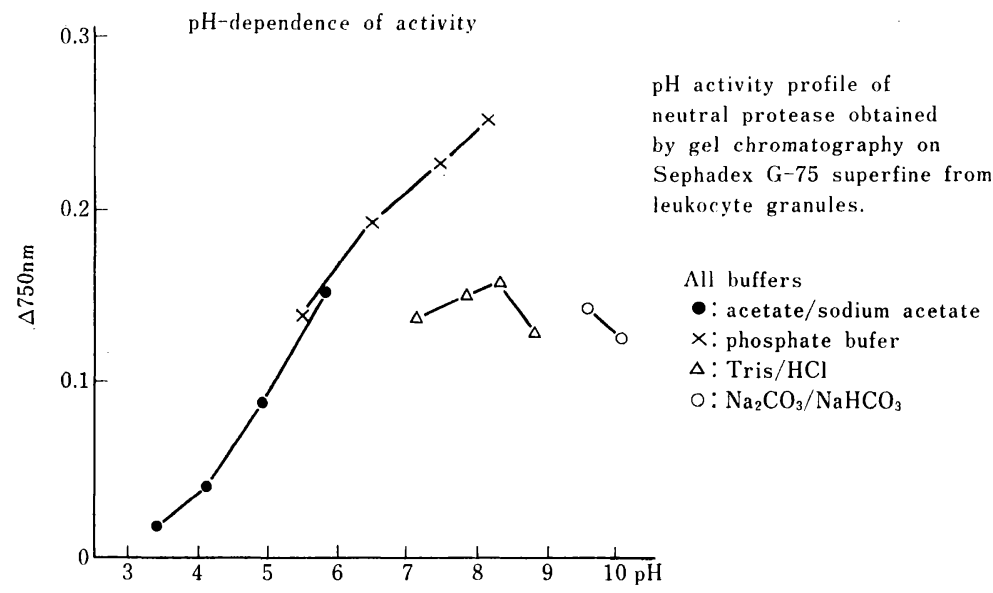

図 $6 \mathrm{pH}$ を変化させた時の protease activity の変化

の上皮基底層と上皮值下固有層に存在する炎症性細胞の 周团の線維束で PAS 陽性度が高かった (図 $15 \mathrm{~A}, \mathrm{~B}, \mathrm{C}$ )。 これらの組織像は顆粒抽出液を滴下した例において著明 に認められた。

\section{IV. 考察}

最近炎症過程に伴なう組織破壊において, 多形核白血
球由来のライソゾーム酵素が果たす役割について注目さ れている。歯周疾患の病因としても，このことに関心が 向けられてきている。

本研究もヒト白血球からライソゾーム酵素を抽出し, こがれ in vivo において歯周組織にどのような変化をむ たらすかということを調べる目的で行なった。

ヒト末梢血から白血球成分を分離する方法としては Dextran 溶液のみを用いて行なった。Ficoll-Isopaque 
表 4 家鬼下顎切歯唇側歯肉溝上皮, 上皮下固有層における変化

\begin{tabular}{|c|c|c|c|}
\hline $\begin{array}{l}\text { Morphologic Characteristic } \\
\text { Assayed* }\end{array}$ & $\begin{array}{l}\text { Granule Fraction. } \\
\text { Treated } \\
\text { (mean of } 6 \text { pockets) }\end{array}$ & $\begin{array}{l}\text { Neutral protease- } \\
\text { Treated } \\
\text { (mean of } 5 \text { pockets) }\end{array}$ & $\begin{array}{l}\text { Control } \\
\mathrm{NaCl}-\mathrm{Treated} \\
\text { (mean of } 6 \text { pockets) }\end{array}$ \\
\hline Pocket Depth & $4.3 \pm 0.5 \mathrm{~mm}$ & $4.4 \pm 0.6 \mathrm{~mm}$ & $3.3 \pm 1.0 \mathrm{~mm}$ \\
\hline $\begin{array}{l}\text { Ulceration } \\
\text { Number of inflammatory } \\
\text { cell of lamina propria }\end{array}$ & $\#\left\{\begin{array}{l}\text { Upper : } 5 \text { poc. } \\
\text { Middle: } 2 \text { poc. } \\
\text { Deeper: } 1 \text { poc. }\end{array}\right.$ & $\begin{array}{l}+\rightarrow \text { Deeper }: 4 \text { poc. } \\
\rightarrow 1 \text { poc. }\end{array}$ & - All pockets \\
\hline Upper portion & $132.5 \pm 45.3 \Delta \boldsymbol{\Delta}$ & $70.8 \pm 25.5 \Delta$ & $31.2 \pm 10.6$ \\
\hline $25 \times 10^{-3} \mathrm{~mm}^{2}$ Middle portion & $114.7 \pm 12.0 \Delta \Delta$ & $126.0 \pm 38.6 \boldsymbol{\Delta}$ & $41.3 \pm 15.1$ \\
\hline Number of leukocyte & $111.7+23.5 \mathbf{A} \mathbf{A}$ & $86.0 \pm 26.7 \boldsymbol{\Delta} \Delta$ & $37.7+8.8$ \\
\hline $\begin{array}{l}\text { infiltrated into epithelium } * * \\
\quad\left(\text { cells } / 12.5 \times 10^{-3} \mathrm{~mm}^{2}\right)\end{array}$ & $87.3 \pm 19.9 \boldsymbol{\Delta} \Delta$ & $40.2 \pm 17.9 \Delta$ & $3.4 \pm 3.4$ \\
\hline
\end{tabular}

* Estimations made with the aid of a eyepiece micrometer gauge

** Mean of the number of cells at upper, middle, deeper portion

*** Mean \pm Standard Deviation

$\Delta: \begin{array}{llll}\Delta & < & \Delta & \Delta\end{array}$

溶液を併用した場合と比較すると単核白血球の混在する 割合が大きいが，得られる白血球数は $50 \%$ 増であると Ishikawa 等 ${ }^{32}$ が報告している。本研究においても単核 白血球が $8.8 \%$, 好酸球, 好塩基球が各々約 $2 \%$ ずつ混 在していたが, 得られた酵素はほとんど多形核白血球由 来のものと考えられる。

また得られた白血球分画に $0.34 \mathrm{M}$ sucrose を加えて ホモジナイズした後 $4^{\circ} \mathrm{C}, 20,000 \mathrm{~g}$ で 20 分間遠沈を行 なって得た沈渣の中にはライソゾームの他にミトコンド リアやペルオキシゾーム等の細胞成分も含まれていると 思われる。どのくらいの割合でライソゾームが存在する か, あるいはアズール顆粒, 特殊顆粒の比率はどの程度 であるのかを確認するためには組織化学的方法等で検索 する必要がある。Sephadex G-75 superfine を用いた ゲル滤過クロマトグラフィーによって得られた溶出パタ ーンは Rindler-Ludwig(3), Fold ${ }^{21)}$, Ishikawa 等22)の結 果と類似していた。そして,その 2 番目のピークが neutral protease の活性を持つことを確認した。

その比活性も Ishikawa 等 ${ }^{22}$ の得た結果に類似した值 を示した。

また Janoff 等 ${ }^{28)}$ が報告しているように，合成基質で ある NBA は elastase のみが特異的に作用する合成基 質である。これを基質に用いて測定すると溶出パターン の 2 番目のピークにエラスターゼ活性が認められた。

これは Fold 等21)による結果と類似していた。Fold 等

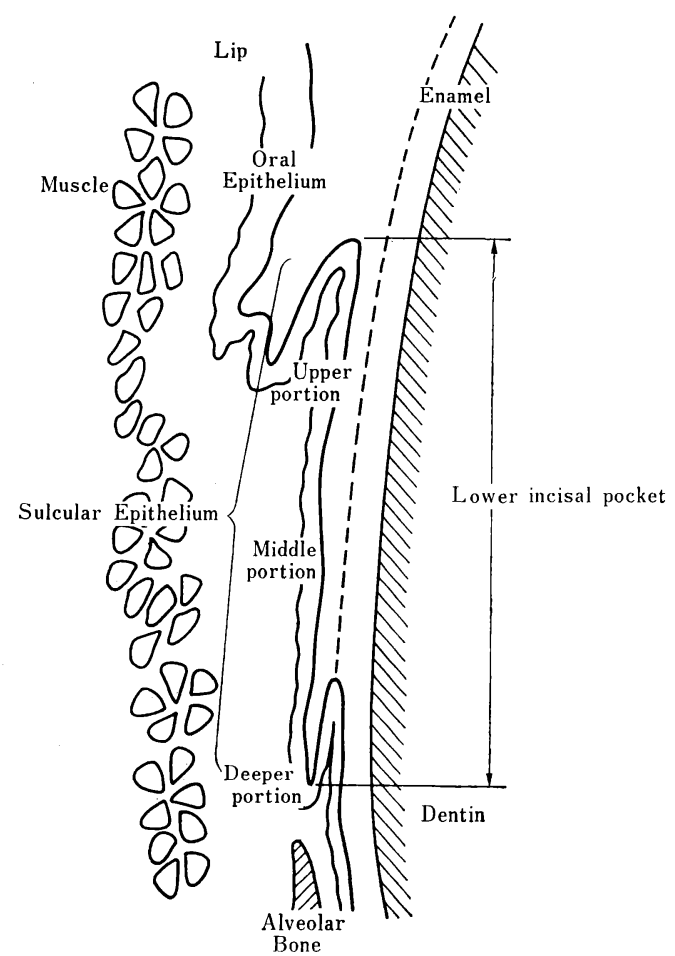

図 7 家鬼下頷切歯唇側部を縦断した模式図 は慢性骨髄性白血病の患者から得た多形核白血球から顆 粒分画を抽出して Sephadex G-100 を用いたゲル滤過ク ロマトグラフィーにおいて溶出パターンに現われた 2 番 


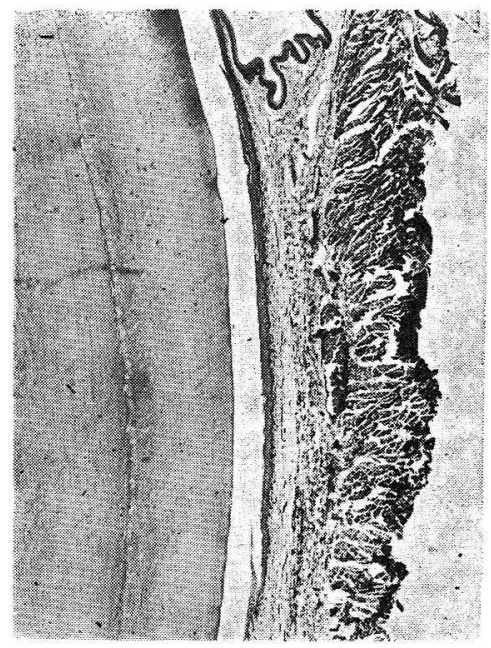

A

歯肉瑇全体 $\times 19$

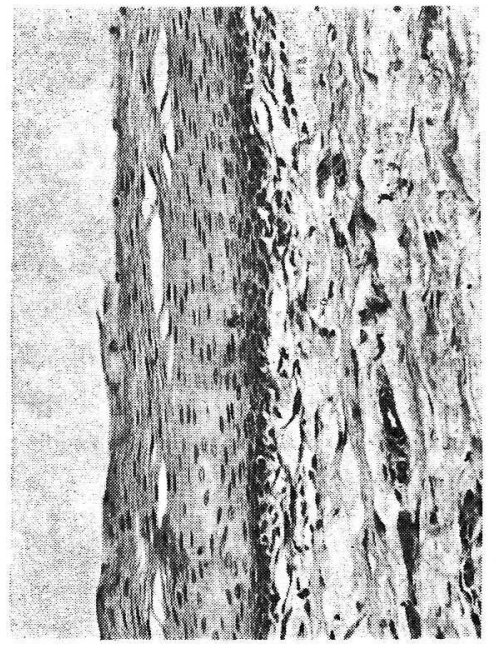

B

歯肉溝上部 $\times 300$

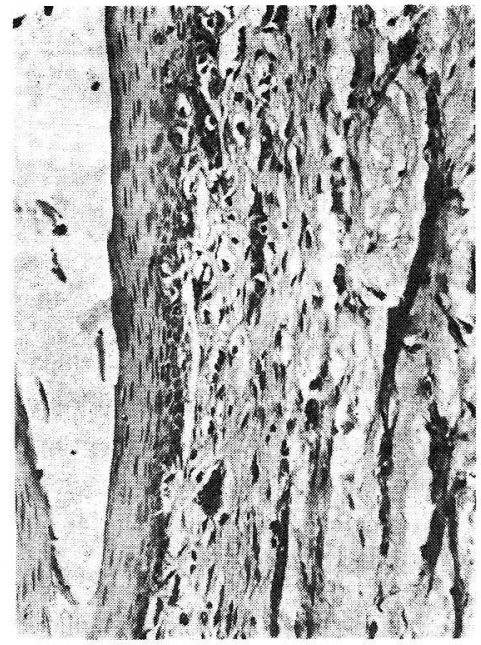

C

歯肉溝底部 $\times 300$

B. C. ともに炎症性細胞浸潤はほとんど見られない。

図 8 生理的食塩水を滴下した群 H.E 染出

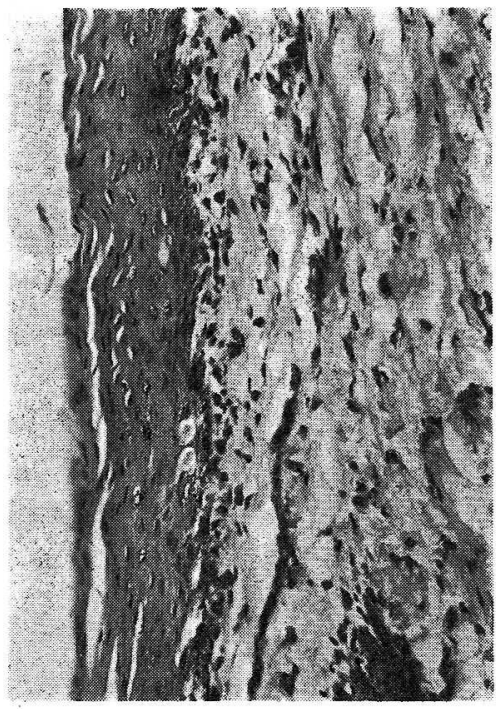

$\mathrm{A}$

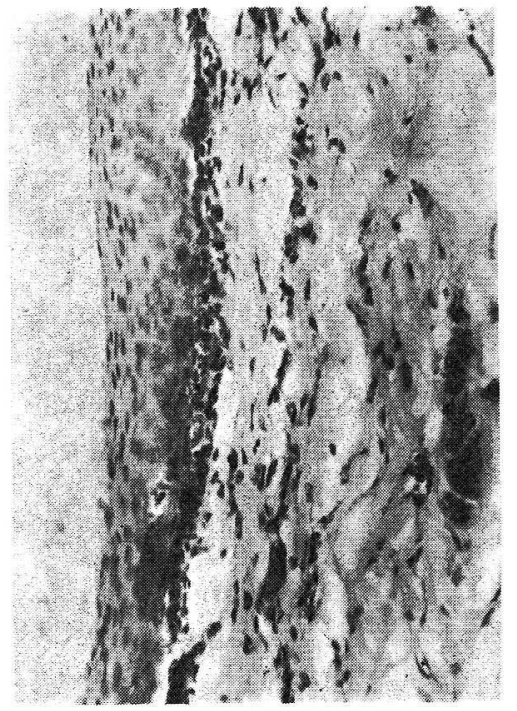

B

歯肉溝上部 $\times 300$

歯肉溝底部 $\times 300$

A. B ともに炎症性細胞浸潤はほとんぞ見られない。

図 9 Grannle extract (顆粒抽出液) を不活性化したものを滴下した群 H-E 染色

目のピークに不溶性の elastin-orcein 混合物, N-benzoyl-DL-phenylalanine-2-naphtyl ester を用いて, エラ スターゼ活性があることを証明している。

Rindler-Ludwing 等33)も Sephadex G-75 を用いたゲ
ル濾過クロマトグラフィーの溶出パターンの 2 番目のピ ークに, 合成基質 $\mathrm{AcAla}_{3} \mathrm{OME}$ ( $\mathrm{N}$-acetyl-1-alanyl-1alanyl-1-alanine methyl ester) を用いてエラスターゼ 活性があることを証明している。次に蛋白分解酵素活性 


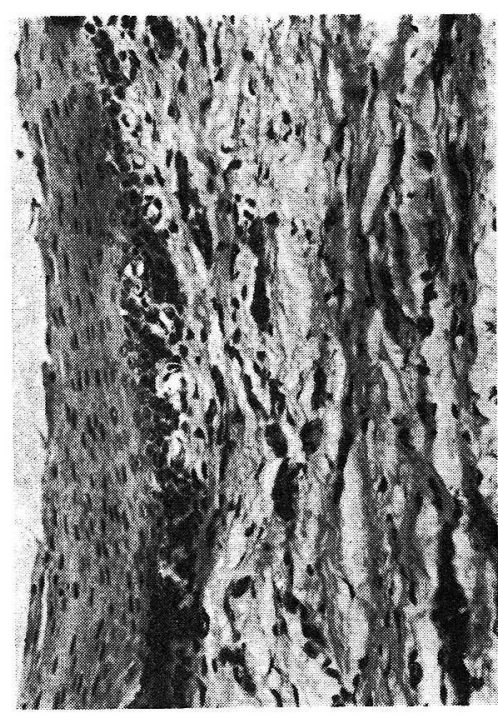

A

歯肉溝上部 $\times 300$

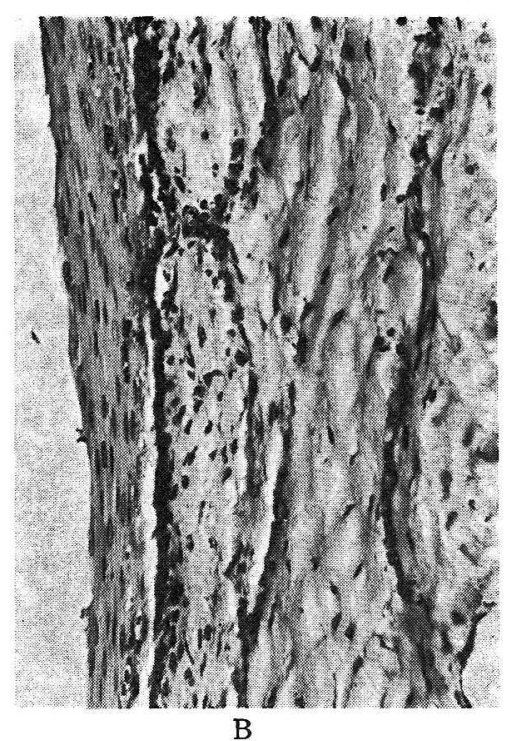

歯肉满底部 $\times 300$

A. B ともに炎症性細胞浸潤はほとんど見られない。

図 10 Neutral protease を不活性化したものを滴下した群 H-E 染色

の $\mathrm{pH}$ 依存性について調べると至適 $\mathrm{pH}$ は 8.3 8.9 で あり, Ishikawa 等22)の結果と類似していた。

今回の奏験ではエラスターゼ活性の $\mathrm{pH}$ 依存性に関し ては定量していないが, Starky 等34はヒト膵茞から得 たライソゾーム由来のエラスターゼについてその $\mathrm{pH}$ 依 存性を定量して, 至適 $\mathrm{pH}$ は8.2 9.2 であるという結 果を得た。

またゲル濾過クロマトグラフィーによって得られた中 性蛋白分解酵素活性とエラスターゼ活性を持つ分画の分 子量は $25,000 \pm 3,000$ で Ishikawa 等の結果 ${ }^{22)}$ と同じ值 を示した。

なお, neutral protease の inhibitor としては, soyabean trypsin inhibitor, ヒト血清等が知られているが, 今回は inhibitor を用いた定量は行なわなかった。従っ て白血球から抽出し部分的に精製して得られた neutral protease については, これが中性領域で蛋白分解酵素活 性を示すこと（至適 $\mathrm{pH} 8.3 \sim 8.9$ ), エラスターゼが特 異的に作用する合成基質 NBA に対して活性を持つこと の 2 つの条件によって同定した。

歯肉溝に拄けるライソゾーム酵素の起源については細 菌由来のものと白血球由来のものの雨方が考えられてい るが, 歯肉溝中に遊出する白血球の中で大きな比率を占 めている多形核白血球が，その顆粒に多量のライソゾー 厶酵素を含むことから，多形核白血球に由来するものが
多いとされている。

Schroeder 等 ${ }^{3}$ は付着上皮の基底部や結合組織中には， 単核白血球が多形核白血球の約 2 倍も多く遊出している と報告していることから，ライソゾーム酵素は単核白血 球にも由来すると考えられる。

Page 等 ${ }^{35}$ によると, macrophage は歯垢中の細菌を 貣食することによりライソゾーム酵素を放出する。

今回の実験のように短時間で行なった場合には多形核 白血球由来のライソゾーム酵素が炎症のメディエーター になり得るが, 炎症に伴って歯周組織が破壞される場合 には, これと同様の現象が多形核白血球とともに, 単核 白血球や macrophage によって組織中で起こるのでは ないかと考えられる。

今回 in vivo でウサギの歯周組織に対して行なった実 験の結果歯肉溝上皮はライソゾーム酵素により容易に崩 壊することが観察された。この歯肉溝上皮の透過性につ いて, 現在までに多くの物質を用いて実験が行なわれて きているが，ての結果は必ずしも一致していない。健全 な歯肉に障害を生じさせるかどうかについても確定して いない。

今日まで酵素を in vivo で歯肉組織に作用させた実験 についても様々な結果が提示されている。

Schultz-Haudt 等 ${ }^{36)}$ はヒトの歯肉溝に hyaluronidase を滴下すると, 上皮細胞閒の拡大や細胞間質の破壊がお 


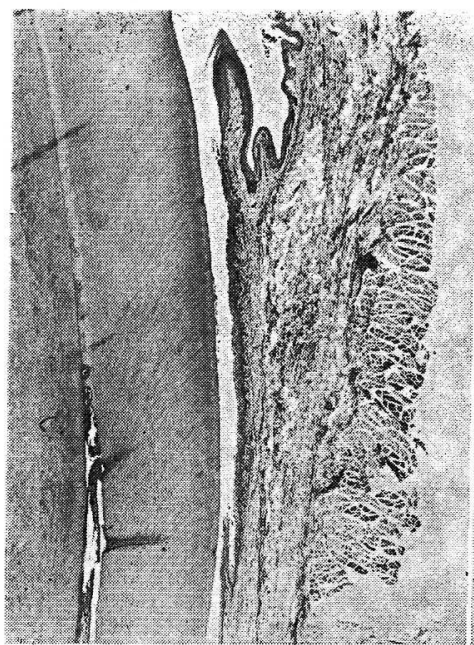

A

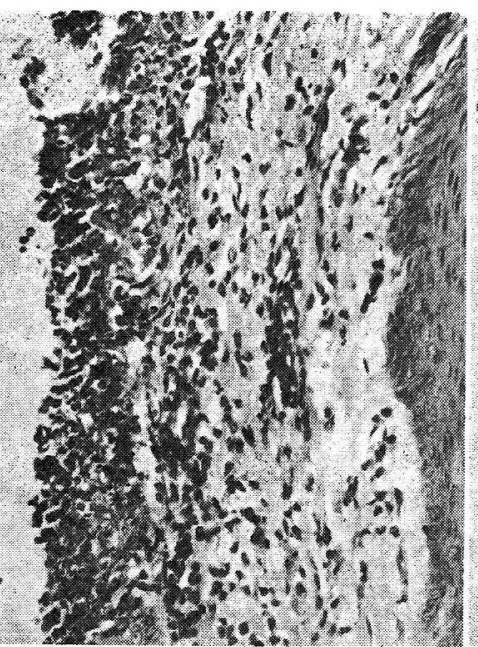

B

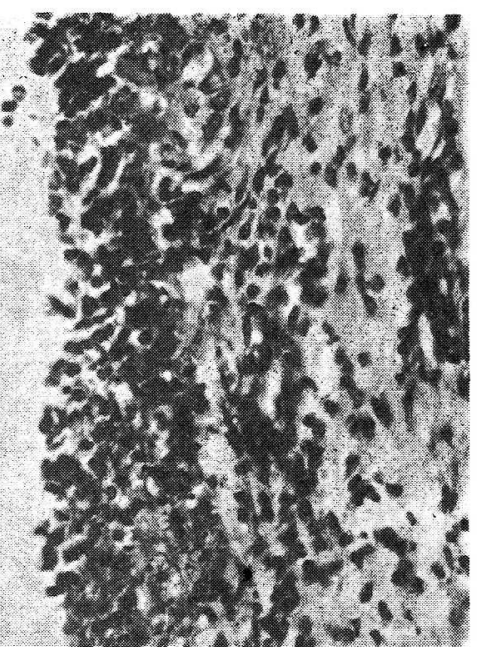

C

歯肉溝全体 $\times 19$

歯肉溝上部 $\times 300$

Bの执大 $\times 500$

上皮中に白血球を主とする炎症性細胞浸潤がおこり一部上皮が崩壊しているのが見られる。

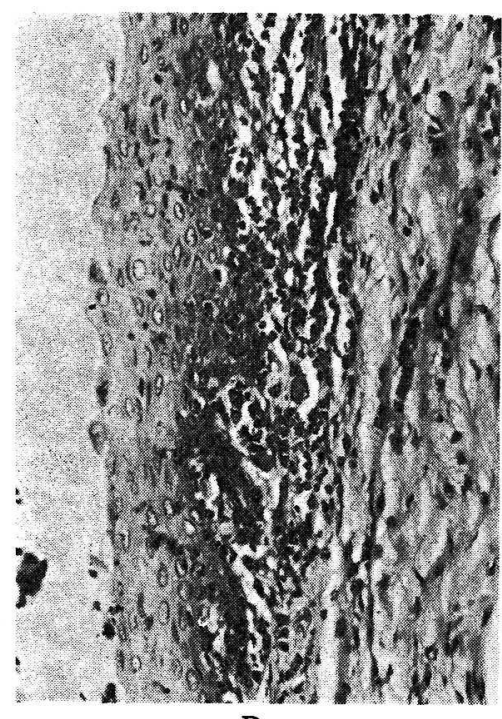

D

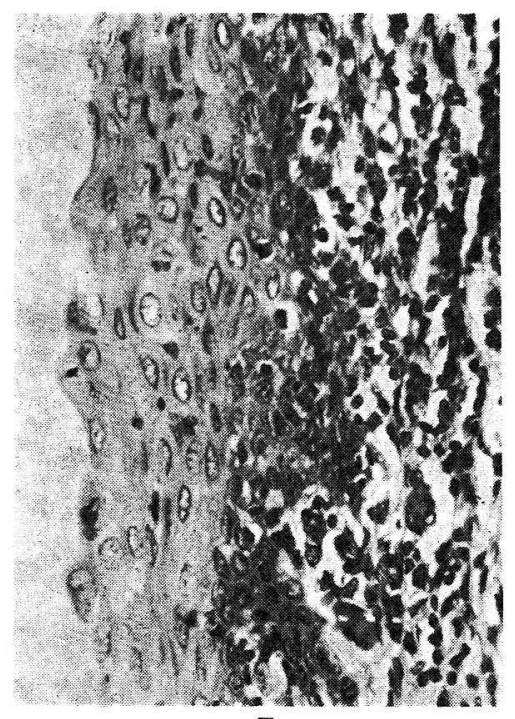

E

歯肉溝底部 $\times 300$

Dの拡大 $\times 500$

上皮中，上皮直下に炎症性細胞浸潤が見られる。

図 11 Granule extract（顆粒抽出液）を滴下した群 $\mathrm{H}-\mathrm{E}$ 染色

こることを確認した。

Thilander ${ }^{37)}$ もト歯肉溝中に被験者の血液から得た 白血球をホモジナイズしたものと hyaluronidase を混 合して滴下すると歯肉溝上皮の細胞間隙が拡大すること を発表した。

Stallard 等 38,39$)$ は squirrel monkey の歯肉溝上皮に hyaluronidase と collagenase の混合物を作用させて屠
殺前にトリチウムを注入し，ラジオオートグラフィーで 調べると，歯肉溝上皮の radioactive index が増加して 上皮の透過性が亢進することを発表した。

また Kraus 等40)によると Clostridium hystryticum の collagenase をウサギの歯肉溝に長時間作用させても 歯肉に病変は起こらず，抗体産生も見られなかった。

以上のように, 歯肉溝上皮の透過性を元進させたり細 


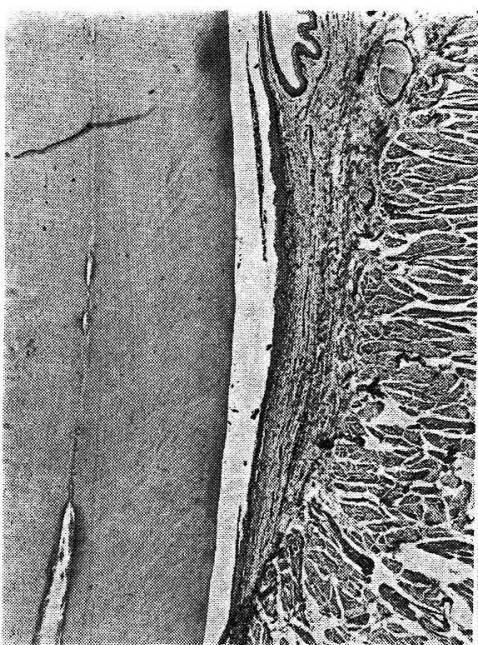

A

歯肉溝全体 $\times 19$

上皮中に白血球の浸潤がおこり部分的に剝離しているのが見られる。

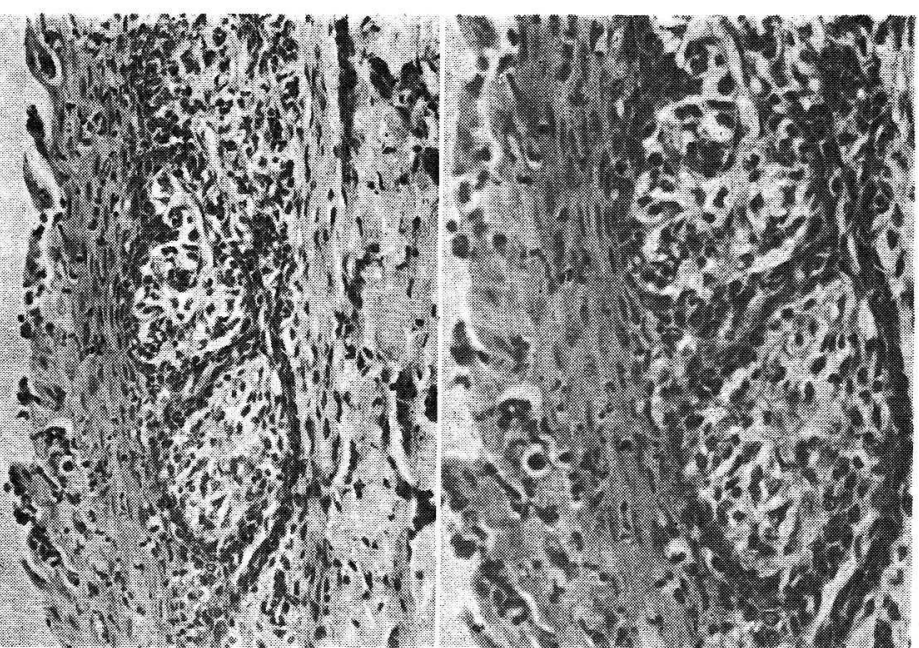

$\mathrm{C}$

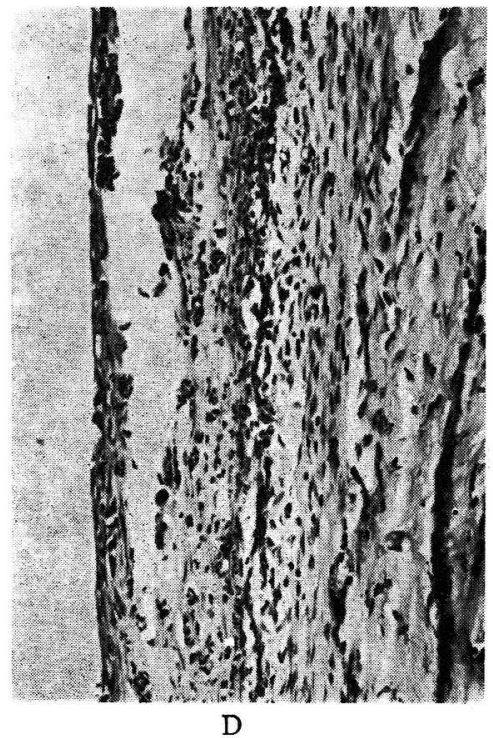

歯肉满底部 $\times 300$

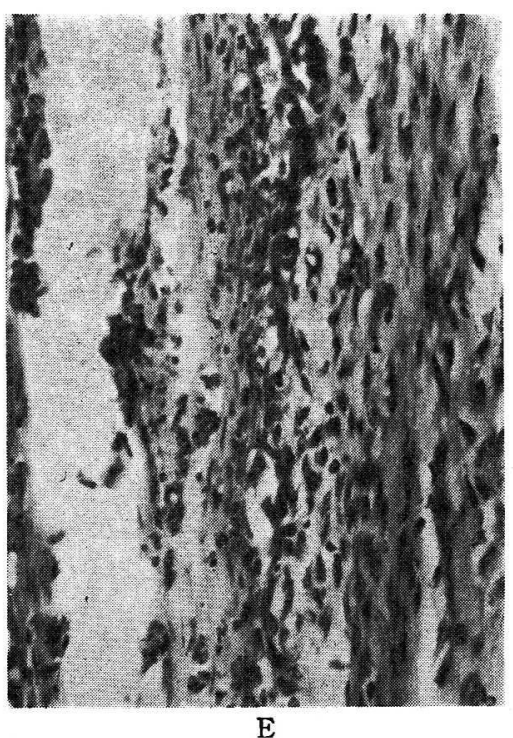

Dの应大 $\times 500$

上皮中，上皮下に白血球の浸潤が見られる。

図 12 Neutral protease を滴下した群 H-E 染他

胞間隙を拡大させる因子の 1 つとして，酵素があげられ てきた。

Cimasoni 等 ${ }^{24)}$ は，炎症が進展するにつれて歯肉中あ るいは歯肉溝浸出液中に増加するラインゾーム酵素の多 くのものが，その分子量から考えると歯肉組織中に侵人 しうることを示唆している。

Heiniger 等 ${ }^{24)}$ にっって in vitro においてライソゾー
ム酵素が歯肉組織を破壊することは確められた。 歯肉溝に打いて，歯垢と歯肉溝上皮との間に存在寸る 多形核白血球が何らかの刺激を受けてライソゾーム酵素 を細胞外に放出し，一時的に高濃度の酵素が存在するこ とが考えられる。

このようなかなり高濃度で，実際に歯肉满中にみられ る加水分解酵素や蛋白分解酵素が健全な上皮の細胞間物 


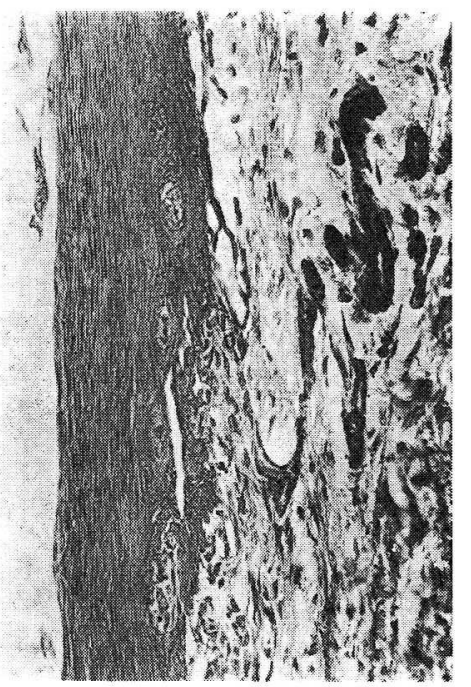

A

生理的食塩水を滴下した 群 歯肉溝上部

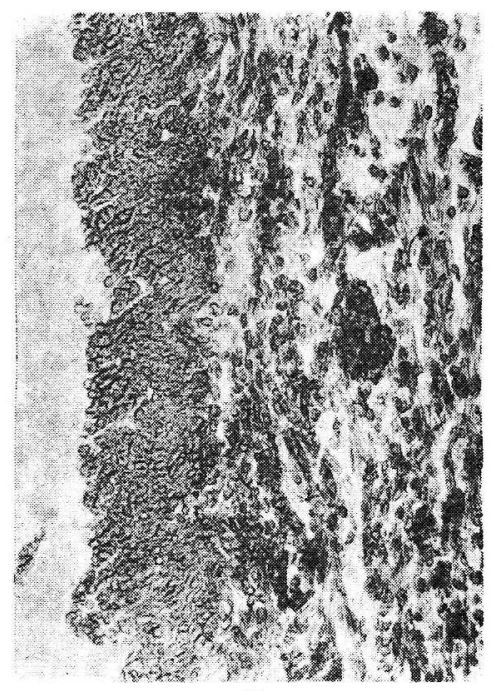

B

顆粒抽出液を滴下した

群 歯肉溝上部

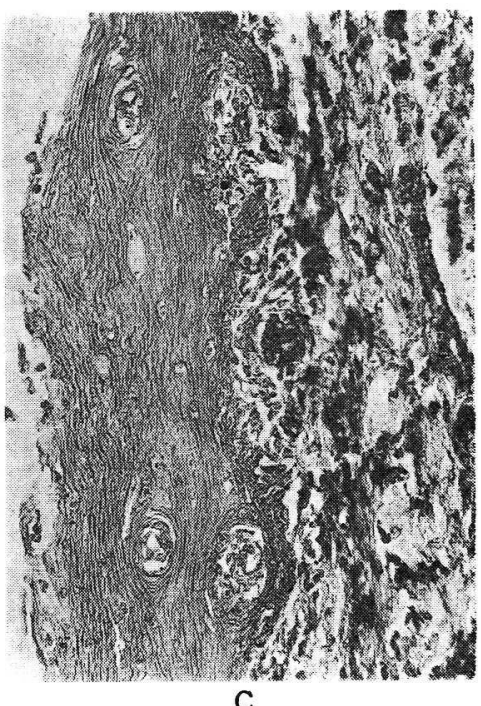

Neutral protease 滴下した群 歯肉溝上部

B. C. 上皮下固有層において炎症性細胞の周囲で染色性が悪く

部分的に線維が消失しているのが見られる。

図 13 アザンマロリー染色を行なった組織標本（×300）

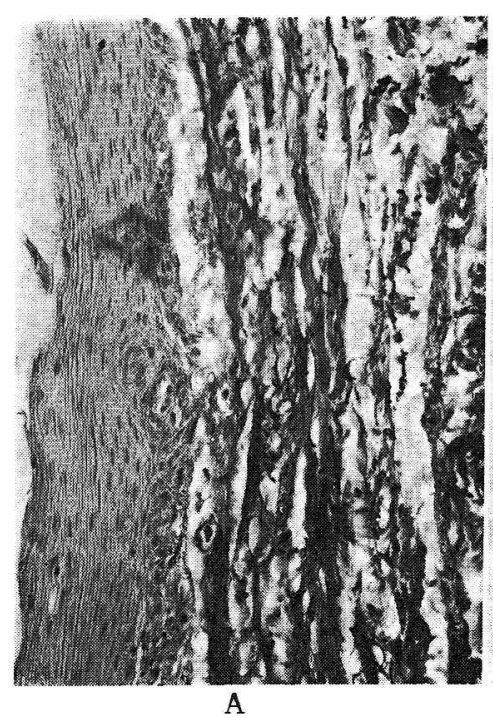

生理的食塩水を滴下した 群 歯肉溝上部

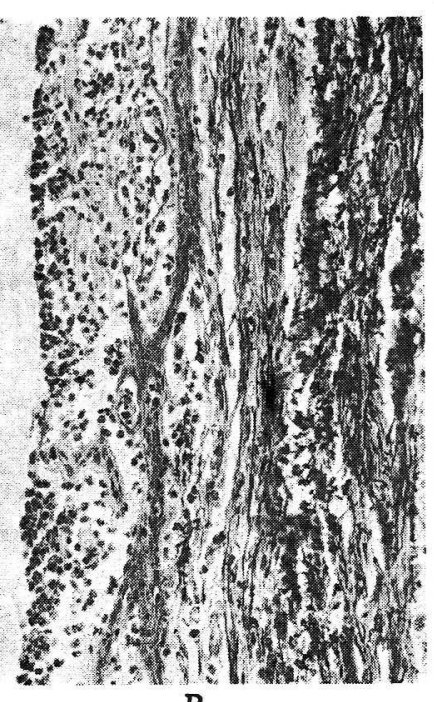

顆粒抽出液を滴下した 群 歯肉溝上部

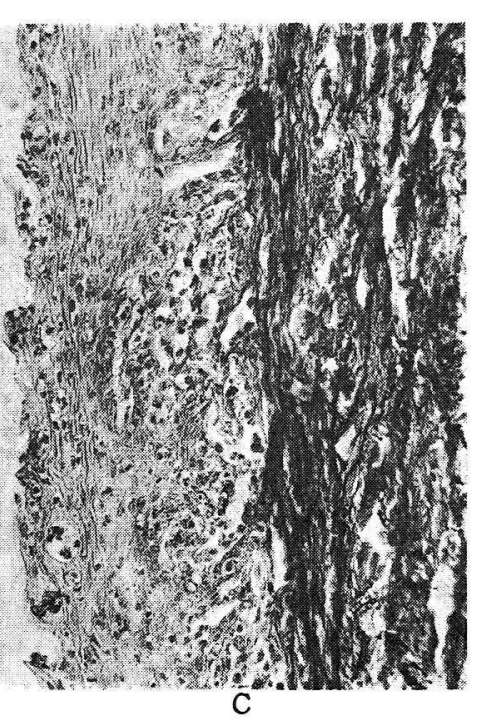

Neutral protease を 滴下した群 歯肉溝上部

B. C. 上皮下固有層において部分的に線維の消失がみられる。

図 14 エラスチカワンギーソン染色を行なった組織標本（×300）

翼や細胞膜を融解できるかどうかを検索するために今回 の実験を行なった。用いた酵素のらち顆粒抽出液を滴下 した例の方が，部分的に精製した neutral protease 滴下した例よりも反応が強く認められた。 neutral pro- tease を単独に作用させるよりも，他の加水分解酵素の 作用を併用させた場合の方が反応が顕著に現われるため だろうと思われる。

その他今回の実験に用いた 2 種類の酵素溶液は, その 


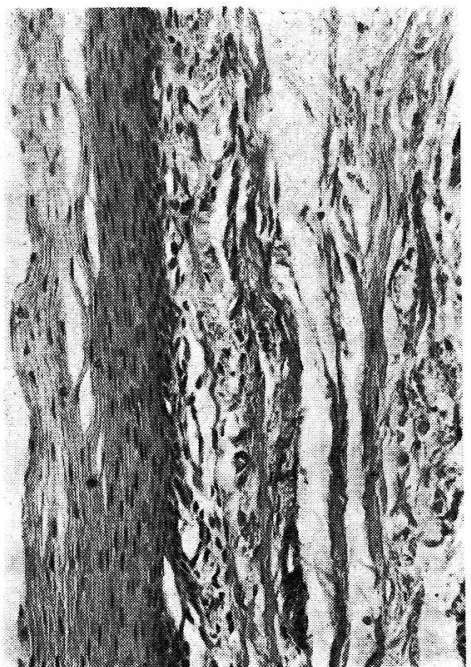

A

生理的食塩水を滴下した 群 歯肉溝上部

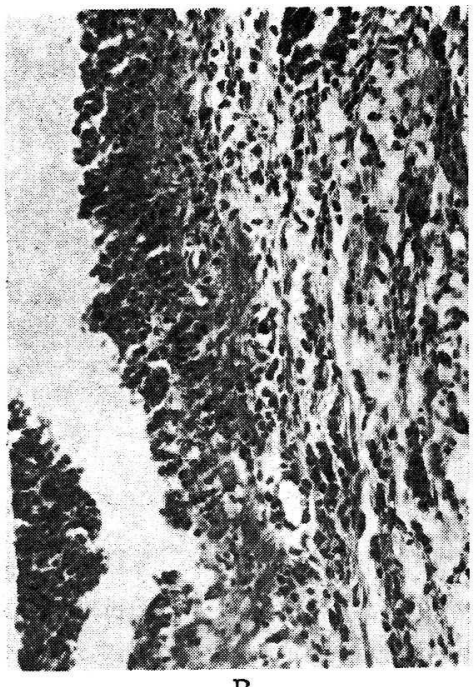

B

顆粒抽出液を滴下した

群 歯肉溝上部

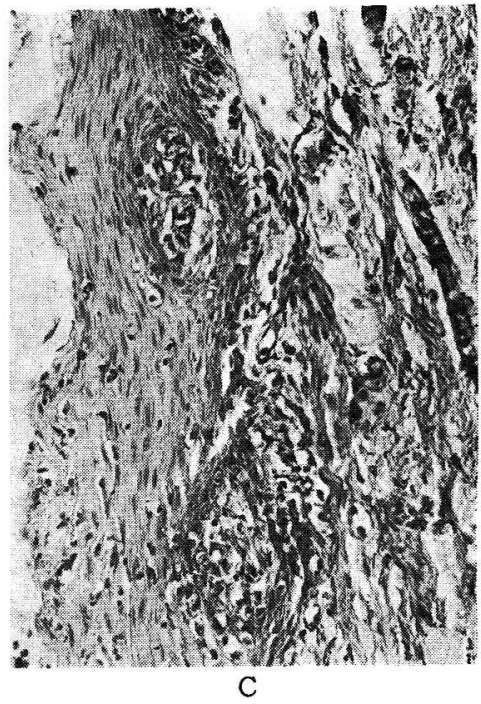

Neutral protease 滴下した群 歯肉溝上部

B. C. 上皮基底層と上皮直下固有層に存在する炎症性細胞の 间囲の線維束で PAS 陽性度が高いことが認められた。

図 15 PAS 染色を行なった組織標本（×300）

中性蛋白分解酵素活性, エラスターゼ活性の両者におい て顆粒抽出液の方が大きかったためであるとも考えられ る。

ライソゾーム酵素を作用させた歯肉溝では, 上皮の細 胞閒隙は抗大しており, 部分的には細胞は破壊されて融 解し, 基底細胞層む認められず，多形核白血球を主とす る炎症性細胞が上皮に侵人し，上皮固有層に浸潤してい る像が特徴的に見られた。しかもこの変化は菌肉溝上部 に多く見出された。

歯肉浸出液の流れが歯肉溝底部から歯冠方向に向から ことを考慮すると, 濾紙片を挿入してその上に酵素溶液 を滴下しても, 浸出液によって大部分は排除されてしま

\section{うことが考えられる。}

部分的に精製した neutral protease を作用させた歯 肉溝においても，潰瘍形成は認められなかったが，上皮 内への多形核白血球を主とする次症性細胞浸潤が顕著に 認められた。

この結果から，歯肉溝に放出された白血球由来のライ ソゾーム酵素は, 直接上皮細胞を融解させるとともに, それ自身が白血球遊走因子として働いて白血球を血管外 に遊走させることを繰り返して組織破壊をひきおこすの ではないかと思われた。

Cornelly 等 ${ }^{41)}$ は多形核白血球のライソゾーム酵素は
補体の関与なしに白血球を遊走させる cytotaxin（直接 作用因子）であると報告している。

さらに最近 Ward 等 ${ }^{42)}$ は, 多形核白血球のライソゾー 么酵素を単核球遊走因子として注目している。

Mergenhagen 等 ${ }^{43)}$ は, 多形核白血球から抽出された ライソゾーム酵素, 特に neutral protease はC 5 に働 きC $5 \mathrm{a}$ を生成させ，このが単核球遊走活性を示すこと から一種の cytotaxigen（閒接作用因子）であるとして いる。

白血球由来のライソゾーム酵素に対する歯㓮組織の反 応過程で補体の関与の有無についてはさらに検索する必 要があると思われる。

さらに今回の実験ではライソゾーム酵素を歯周組織に 適用した時間が短いので言及できないが，炎症における 組織破壊の過程で, 免疫に関与する細胞とライソゾーム 酵素との間に関倸があることが知られている。

Baggiolini 等 ${ }^{19)}$ は, 多形核白血球由来の elastase と cathepsin G は B-リンパ球を刺激して抗体産生を起こ させること, そしてこの作用は酵素濃度に依存し, 血清 や Tーリンパ球の産生物等によって媒介されず, 酵素の リンパ球細胞膜に対する直接的な蛋白分解酵素活性によ ることを報告している。

Yamasaki 等 ${ }^{44)}$ もト多形核白血球のライソゾーム顆 
粒抽出液を用いて，ヒトリンパ球の免疫グロブリン産生 克進がおこることを認めている。

さらに Yamasaki ${ }^{45)}$ 等は, リウマチ性関節炎患者の 関節炎と末梢血中のリンパ球, 及び正常人の末梢血中の リンパ球に対して，患者の関節液や正常人の未梢血から 得た多形核白血球顆粒抽出液を加えると, いずれの場合 に掠いても PHA 添加リンパ球の幼若化が増強されるこ と, そして多形核白血球顆粒抽出液を Sephadex G-100 を用いてゲル濾過クロマトグラフィーを行なって得られ た第 2 分画に PHA 添加リンパ球の若幼化に対する刺激 活性があり，これは蛋白分解酵素であることを明らかに した。

以上の研究により, ヒト多形核白血球由来の neutral protease には B-リンパ球を刺激し免疫グロブリン産生 を光進させるとともに, Tーリンパ球を介する細胞性免 疫反応をも増強する活性があることが示唆された。

このことは歯周疾患においては直接確認されていない が, リウマチ性関節炎の病因と同様に, 歯周組織での炎 症の遷延化に损いてもライソゾーム酵素がそのひき金と なり得ると思われる。

これらの研究結果を考虑すると, どのくらいの蛋白分 解酵素活性及びエラスターゼ活性を持つ白血球のライソ ゾーム酵素が作用する時に組織破壊が始まるのかという こと, また酵素活性と作用時間の関係, 即ちどのくらい の酔素活性をもつものが, どの程度の時間作用すれば組 織に損傷を与え, リンパ球に対しても刺激を与え得るか ということ,さらにこれらの作用に対する inhibitor の 影響等を明らかにすることは重要であると思われる。

本研究では被験動物としてウサギを用いたが，ウサギ の多形核白血球は七トのそれに比較して中性蛋白分解酵 素活性が低く, ヒトの $1 / 10 \sim 1 / 30$ の值を示す ${ }^{19)}$ 。中性 蛋白分解酵素活性のみを考元ると, ヒトの多形核白血球 から得た酵素をウサギの歯肉溝に作用させる場合は, ウ サギ多形核白血球から得た酵素をウサギ歯肉溝に作用さ せるよりも大きな変化が得られる可能性があるだろう。

しかしウサギの歯肉溝における neutral protease に 対する inhibitor に関して研究を行なっていないので, 反応の差違について検討することはできなかった。

Ohlsson 等 ${ }^{25}$ はヒト歯肉溝中に neutral protease に対 する血清中の inhibitor である $\alpha_{1}$-antitrypsin, $\alpha_{2}$-macroglobulin が存在しており, 炎症歯肉では inhibitor の量 も増加することを確めて, neutral protease の作用がこ れらの inhibitor によって調節され得ることを示唆し た。
本研究では, in vivo においてヒト白血球由来の酵素 の作用を追求するために 1 つの実験系を用いた。そして この実験から，ヒト白血球由来の酵素がウサギ歯肉溝上 皮を破壊することを組織学的に確認することができた。

今後, 実験動物, 醭素活性, 䤉素の作用時間, inhibitor 等の問題について検討を加えて, より詳細にライソジー ム酵素が歯周組織に及ぼす影響について追求することは 歯周疾患の成り立ちを考える上で意義があると思われ る.

\section{V. 結 論}

ヒト白血球からライソゾーム顆粒を含む分画を分離 し，顆粒抽出液を抽出し，これをゲル濾過クロマトグラ フィーにより部分的に精製して neutral protease を得 て, 生化学的検索を行なった。

さらにこれらの酵素を in vivo でウサギの歯肉溝に滴 下して，これらが歯肉溝上皮に病的変化を誘発するかど らかについて調べたところ，以下に述べる結果を得た。

1）ヒト白血球から得た neutral protease の分画は 中性蛋白分解酵素活性とエラスターゼ活性の両者を持つ 特異的な酵素の分画であることを確認した。

2）家鬼の下顎切歯唇側歯肉溝に濾紙片を雨人し i) ヒト白血球から抽出した granule extract（顆粒抽出液） ii）i）を部分的に精製して得られた neutral protease iii）Control として生理的食塩水，及び i)，ii）を加熱 して不活性化したものを 10 分間隔で 6 時間滴下した。

歯肉の変化を歯肉溝上部, 中間部, 底部の 3 部位に分 けて, そこにおける潰瘍の有無, 上皮值下固有層の炎症 性細胞の数, 上皮へ侵入した白血球数について観察し た。

実験側では炎症性細胞の数, 上皮中の白血球数が統計 学的に有意に増加していた。またi）を滴下した歯肉溝 上皮には全ての例に㧤いて潰瘍が見られた。対照群では 変化は見られなかった。

謝辞 稿を終わるに臨み, 終始, 御愍篤な御指導と御校閲を 賜わった木下四郎教授に謹しんで感謝の意を表します。

また懇切丁寧な御教示と御校閲を戴きました石川烈講師, 本 学生化学教室の佐々木哲教授に心からの感謝を捧げます。

さらに実験に際し御指導, 御協力下さいました末四武助教授 をはじめとする第 2 粜科保存学教室諸兄に感謝いたします。 併せて実験に際し御便宜を図っていただいた生化学教室, 検 查部, 口腔細菌学教室諸兄, 貴重なる血液を提供して下さいま した日赤血液供給課諸兄, 本学蔽学部学生諸兄, 及び本学写真 
部諸兄，動物施設諸兄に謹しんで謝意を表します。 この研究の一部は文部省の科学研究費の援助を受けた。

\section{文献}

1) Attström, R. : Presence of leukocytes in crevices of healthy and chronically inflamed gingivae. J. Periodontal Res. 5 :42-47, 1970.

2) Schiött, C.R. and Löe, H. : The origin and variation in number of leukocytes in the human saliva. J. Periodontal Res. $5: 36-41$, 1970.

3) Schroeder, H.E. : Transmigration and infiltration leukocytes in human junctional epithelium. Helv. Odont. Acta. $17: 6-18,1973$.

4) Attström, R. : The roles of gingival epithelium and phagocytosing leukocytes in gingival defence. J. Clin. Periodontol. 2 : 25-32, 1975.

5) Jensen, S.B., Theilade, E. and Jensen, J.S. : Influence of oral bacterial endotoxin on cell migration and phagocytic activity. J. Periodontal Res. 1. : 129-140, 1966.

6) Hellden, L., Lindhe, J., Attström, R. and Sundin, Y. : Neutrophil chemotactic factors in gingival crevice material. Helv. Odont. Acta $17: 1-5,1973$.

7) Garant, P.R. : Plaque-neutrophil interaction in monoinfected rats as visualized by transmission electron microscopy. J. Periodontol. 47 : 132138, 1976.

8) Garant, P.R. : An electron microscopic study of the periodontal tissues of germ-free rats and rats monoinfected with Actinomyces naeslundii. J. Periodontal Res. Suppl. 15 : 1-79, 1976.

9) Lange, D. and Shroeder, H.E. : Cytochemistry and ultrastructure of gingival sulcus cells Helv. Odontol. Acta 15, Suppl. 6 : 65-86, 1971.

10) Brantzaeg, P. : Local factors of resistance in the gingival area. J. Periodontal Res. 1. : 1942, 1966.

11) Freedman, H.L., Listgarten, M.A. and Taichman, N.S. : Electron microscopic features of chronically inflamed human gingiva. J. Periodntal Res. 3 : 313-327, 1968.
12) Wilton, J.M.A., Renggli, H.H. and Lehner, T. : A functional comparison of blood and gingival inflammatory polymorphonuclear leukocytes in man. Clin. Exp. Immunol. 27 : 152-158, 1977.

13) Baehni, P., Tsai, C.C., Taichman, N.S. and McArther, W. : Interaction of inflammatory cells and oral microorganisms V. Electron microscopic and biochemical study on the mechanisms of release of lysosomal constituents from human polymorphonuclear leukocytes exposed to dental plaque. J. Periodontal Res. 13 : 333-348, 1978.

14) Tsai, C.C., Hammond, B.F., Baehni, P., McArther, W.P. and Taichman, N.S. : Interaction of inflammatory cells and oral microorganisns VI. Exocytosis of PML lysosomes in response to Gram-negative plaque bacteria. J. Periodontal Res. $13:$ 504-512, 1978.

15) McComb, R.J. and Trott, J.R. : The effect of endotoxin and complement on the release of lysosomal enzymes from mouse leukocyte in vitro. Arch. Oral Biol. 19 : 125-129, 1974.

16) Goldstein, I.M., Brai, M., Osler, A.G. and Weissmann, G. : Lysosomal enzyme release from human leukocytes: Mediation by the alternate pathway of complement activation J. Immunol. $111:$ 33-37, 1973.

17) Kelstrup, J. and Theilade, E. : Microbes and periodontal disease. J. Clin. Periodontol. 1 : 15-35, 1974.

18) Leffell, M.S., and Spitznagel, J.K. : Intracellular and extracellular degranulation of human polymorphonuclear azurophil and specific granules induced by immune complexes. Infect. Immun. $10:$ 1241-1249, 1974.

19) Baggiolini, M., Bretz, U., Dewald, B. and Feigensen, M.E. : The polymorphonuclear leukocyte. Agents and Actions 8/1-2:3-10, 1978.

20) Goldstein, I.M. : Polymorphonuclear leukocyte lysosomes and immune tissue injury. Progr. Allergy $20: 301-340 ; 1976$.

21) Fold, J.D., Prince, H. and Spitznagel. J.K. : 
Limited cleavage of human immunoglobulins by elastase of human neutrophil polymorphonuclear granulocytes. Laboratory Investigation $39:$ 4, 313-321, 1978.

22) Ishikawa, I. and Cimasoni, G. : Partial purification of neutral protease from human polymoryhonuclear leukocytes and its proteolytic effect on immunoglobulin G. Arch. Oral Biol. 23 : 933-940, 1978.

23) Janoff, A. and Blondin, J.: The effect of human granulocyte elastase on bacterial suspensions. Lab. Invest. 29 : 454-457, 1973.

24) Lehner, T.: The borderland between caries and periodontal disease. (Cimasoni, G., Ishikawa, I. and Jaccard, F. : Enzyme activity in the gingival crevice) Academic Press, London 13-41, 1977.

25) Ohlsson, K., Olsson, I. and Tynelius-Bratthall, G. : Neutrophil leukocyte collagenase, elastase and serum protease inhibitors in human gingival crevices. Acta Odont. Scand. $31: 51-59$, 1973.

26) Fallon, H.J., Frei, E., Davidson, J.D., Trier, J.S. and Burk, D. : Leukocyte preparations from human blood: Evaluation of their morphologic and metabolic state. J. Lab. Clin. Med. 59 : 779-791, 1962.

27) Lowry, O.H., Rosebrouph, N.J., Farr, A.L. and Randall, R.J. : Protein mesurement with the Folin phenol regent. J. Biol. Chem. 193 : 265-275, 1951.

28) Janoff, A. : Alanine p-nitrophenyl esterase activity of human leukocyte granules. Biochem. J. $114:$ 157-159, 1969.

29) Visser, L. and Blout, E.R. : The use of pnitrophenyl N-tert-butyloxycarbonyl-L-alaninate as substrate for elastase. Biochem. Bio. phys. Acta $268: 257-260,1972$.

30) Andrews, P.: The gel filtration of proteins related to their molecular weights over a wide range. Biochem. J. 96 : 595-606, 1965.

31) Rizzo, A.A. and Mitchell, C.T. : Chronic allergic inflammation induced by repeated deposition of antigen in rabbit gingival pockets.
Periodontics $4: 5-10,1966$.

32) Ishikawa, I. and Cimasoni, G. : Isolation of Cathepsin D from human leukocytes. Biochem. Biophysica Acta 480 : 228-240, 1977.

33) Rindler-Ludwig, R., Schmalzl, F. and Braunsteiner, H. : Esterases in human neutrophil granurocytes: evidence for their protease nature. British Journal of Haematology 27 : 57-64, 1974.

34) Starky, P.M. and Barrett, A.J. : Human lysosomal elastase: Catalytic and immunological properties. Biochem. J. 155 : 265-271, 1976.

35) Page, R.C., Davies, P. and Allison, A.C. : Effects of dental plaque on the production and release of lysosomal hydrolases by macrophages in culture. Arch. Oral Biol. 18 : 14811495, 1973.

36) Schultz-Haudt, S., Dewar, M. and Bibby, B.G. : Effects of hyaluronidase on human gingival epithelium. Science $117: 653-655,1953$.

37) Thilander, H. : The effect of leukocytic enzyme activity on the structure of the gingival pocket epithelium in man. Acta Odont. Scand. $20:$ 431-451, 1963.

38) Murphy, P.J. and Stallard, R.E. : An altered gingival attachment epithelium : A result of the enzyme hyaluronidase. Periodontics 6 , No. 3, 105-108, 1968.

39) Stallard, R.E. and Awwa, I.A. : The effect of alterations in external environment on the dentogingival junction. J. Dent. Res. Suppl. No. 5, $48: 671-675,1969$.

40) Kraus, F.W., Mestecky, J., and Grupe, H.E. : Immune response to clostridial collagenase in gingiva and other tissues of the rabbit. J. Dent. Res. Suppl. No. 2, $51: 293-301$, 1972.

41) Cornely, H.P. : Reversal of chemotaxis in vitro and chemotactic activity of leukocyte fractions. Proc. Soc. Exp. Biol. Med. 122 : 831-835, 1966.

42) Ward, P.A. : Chemotaxis of mononuclear cells. J. Exp. Med. 128 : 1201-1221, 1968.

43) Snyderman, R., Altman, L.C., Hausman, M.S. 
and Mergenhagen, S.E. : Human mononuclear leukocyte chemotaxis J. Immunol. 108 : 857860, 1972.

44) Yamasaki, K. and Ziff, M. : Enhancement of in vitro immunoglobulin synthesis of human Iymphocytes by lysosomal enzymes from poly- morphouclear leukocytes. Clin. Exp. Immunol. 27 : 254-260, 1977.

45）山前邦臣, 原まさ子, 安倍 達, 本間光夫 : ライ ソゾーム酵素と免疫反応, 特集 自己免疫疾患組 織障害の機序, 臨床免疫 $9(9): 671 \sim 677,1977$. 